\title{
A new culture medium for Protozoa.
}

\section{By RH. ERD MaNN.}

\section{[From the Osborn Zoological Laboratory, Yale University.]}

Although there are many media extant for cultivating trypanosomes in test tubes, a satisfactory medium for culture on a slide under a cover glass has hitherto not been described, in spite of the fact that only by the slide method is it possible to study the sequence of changes with the greatest accuracy. The method here outlined makes possible the continued study of the life history of the organism either in prepared culture medium or in inoculated tissue.

As a culture medium the plasma of the host is employed and this is either inoculated with the trypanosomes themselves or used as a medium for the growth in vitro of various infected tissues of the host. I have used the plasma of the rat in studying the development of Trypanosoma brucei and have been able to keep the trypanosomes in a normal condition for an indefinite period whereas by the use of Ringer's fluid or blood bouillon the organisms die after a few days.

The plasma was obtained by the method of Harrison, ${ }^{1}$ Burrows, ${ }^{2}$ and Walton, ${ }^{3}$ the latter making adaptations for mammalian plasma. In brief, the blood from the infected rat was taken and put into a small drop of plasma on a cover glass and then this was further diluted with plasma in order to reduce the number of blood corpuscles in the hanging drop which was taken from this. The cover glass with hanging drop was either placed on a depression slide or

${ }^{1}$ Harrison, R. G. Observation on the living developing nerve fiber. Proc. Soc. Exp. BIOL. AND MED., 1907, Vol. IV, p. 140-46. The outgrowth of the nerve fiber as a mode of protoplasmic movement. Journ. Exp. Zool., I9Io, Vol. IX, p. $787-848$.

${ }^{2}$ Burrows, M. T. The cultivation of tissues of the chick embryo outside the body. Journ. of the Amer. Med. Ass., rgro, Vol. LV. The growth of tissues of the chick embryo outside the animal body, with special reference to the nervous system. Journ. Exp. Zool., I9II, Vol. X, p. 63-83.

${ }^{3}$ Walton, A. J. Variation in the growth of adult mammalian tissue in autogenous and homogenous plasma. Proc. R. S. L., Ser. B., Vol. 87, p. 452-6r. 
on a regular slide for study with dark field illumination. In essentially the same way pieces of tissue were placed in plasma under a cover glass and sealed. Precautions to secure aseptic conditions were taken.

This method keeps trypanosomes living, growing and dividing, and thus many of the stages described by various authors either in the host itself or in the transmitter have been studied in vitro. It is evident that this method may be employed not only for blood parasites but for all protozoan forms which are parasites in cells and thus affords another method of approach for the solution of the complicated life cycles of parasitic Protozoa.

\section{$37(969)$}

The influence of depancreatization upon the state of glycemia following the intravenous injection of dextrose in dogs.

\section{By I. S. Kleiner and S. J. Meltzer.}

[From the Department of Physiology and Pharmacology of the Rockefeller Institute for Medical Research.]

In former experiments ${ }^{1}$ it was shown that after the intravenous injection of large amounts of dextrose ( $4 \mathrm{~g}$. per kilo) into dogs the sugar rapidly disappears from the blood stream so that after $I / 2$ hours after the end of the injection the blood-sugar falls nearly to its original figure. In the present experiments the same procedure was carried out on completely depancreatized dogs. In these cases the blood-sugar did not fall to its original value or near it; at the end of $I / 2$ hours it was on the average more than twice as high. The following is a comparison of the average figures:

\begin{tabular}{|c|c|c|c|c|}
\hline & \multicolumn{3}{|c|}{ Blood-sugar. } & \multirow[b]{2}{*}{$\begin{array}{l}\text { Dextrose in Urine, } \\
\text { Per Cent. of Amount } \\
\text { Injected. }\end{array}$} \\
\hline & $\begin{array}{c}\text { Before } \\
\text { Injection. }\end{array}$ & $\begin{array}{c}\text { End of } \\
\text { Injection. }\end{array}$ & $\begin{array}{l}\mathbf{1} \frac{1}{2} \text { Hours After } \\
\text { End of } \\
\text { Injection. }\end{array}$ & \\
\hline $\begin{array}{l}\text { Normal }(5) \ldots . . . . . \\
\text { Depancreatized (9). }\end{array}$ & $\begin{array}{l}0.20 \\
0.38\end{array}$ & $\begin{array}{l}0.79 \\
\text { I.I9 }\end{array}$ & $\begin{array}{l}0.27 \\
0.86\end{array}$ & $\begin{array}{c}>43 \% \\
49 \% \\
\text { (uncorrected for } \\
\text { "diabetic" sugar). }\end{array}$ \\
\hline
\end{tabular}

${ }^{1}$ See Proceedings of the American Physiological Society, Vol. 33, I9r3, p. xxvii. 